\title{
A comprehensive review of lignocellulosic biomass and potential production of bioenergy as a renewable resource in Pakistan
}

\author{
Mohammad Siddique 1,2 *, Suhail Ahmed Soomro1, Hijaz Ahmad ${ }^{3}$, Gull Karam \\ khan $^{4}$ \\ ${ }^{1}$ Department of Chemical Engineering, Mehran University of Engineering \& Technology, Jamshoro, Pakistan \\ ${ }^{2}$ Department of Chemical Engineering, BUITEMS, Quetta, Pakistan \\ ${ }^{3}$ Section of Mathematics, International Telematics University Uninettuno, Corso Vittorio Emanuele II, 39, \\ 00186, Roma, Italy \\ ${ }^{4}$ Gajju khan Medical College Swabi, Pakistan
}

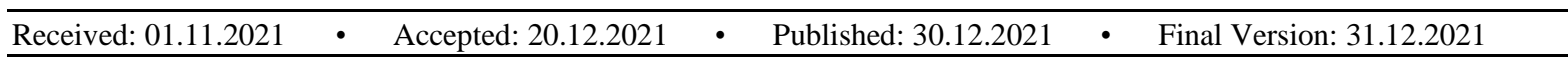

\begin{abstract}
Because it is environmentally friendly energy, lignocellulosic biomass is regarded as one of the most promising energy sources. Lignocellulosic biomass, which is obtained from agricultural waste and forest debris, is the only renewable energy source that contains carbon and is an excellent resource for biofuels and chemicals conversion. In a future of population explosion, growing energy consumption, global warming, and decreasing fossil fuels, pyrolysis of lignocellulosic biomass is seen as a long-term viable alternative source of energy. The main aim of this paper is to synthesize and extract lignin from biomass. To decompose lignin material by pyrolysis heated and convert into biochar at high temperature in the absence of oxygen. This research looks at the new technologies that are being utilized to convert bioenergy waste into energy, as well as the future paths for Pakistan's bioenergy environment policy. The article outlines the overall progress on Pakistan's existing biofuel use scenario, as well as the potential for biofuels and fertilizer, as well as the economic advantages of biofuels over conventional fuels. Ultimately, we explore the role of biomass in biorefining as a way for regulating its consumption to achieve fossil-fuel independence.
\end{abstract}

Keywords: lignin, agriculture residues, waste, biofuel, biochemical conversion, biogas, renewable energy

\section{Introduction}

Agriculture remains a vital component of Economic growth and poverty reduction. It is the world's second-largest sector, employing over half of the population and accounting for $21 \%$ of GDP. Livestock is the most significant depositor in agriculture. It accounts for approximately 53.2 percent of agricultural value-added and, as a result, 11\% of GDP [1]. Energy is a fundamental limiting element in industrialized countries that contributes to stagnation [2]. Crop output is limited by the energy constraint, and Pakistan's growth rate for 2009-2010 was -2 percent. Food is responsible for almost 20\% of Pakistan's foreign exchange [3]. Pakistan spent $\$ 7$ billion on imported conventional energy resources, accounting for $40 \%$ of total imports. Despite the country's chronically limited resources, Pakistan's energy needs are anticipated to quadruple by 2050, according to meticulous predictions [4]. Alternative energy sources should be investigated as quickly as possible. Biogas is a distributed form of renewable energy that is unlike any other renewable resource. Animals and agricultural waste are used to generate bioenergy in practically every rural household. About $15 \%$ 
of worldwide energy consumption is accounted for by biomass, with emerging countries accounting for $38 \%$. A household in Pakistan that uses entirely biomass for energy consumes about $2325 \mathrm{~kg}$ of firewood, $1480 \mathrm{~kg}$ of dung, or $1160 \mathrm{~kg}$ of agricultural leftovers each year [5].

Thermochemical processes such as pyrolysis are used to create biofuels from bio-based materials [7] the process of gasification. The word "liquefaction" refers to the process of something being liquid, extraction of supercritical fluid, liquefaction of supercritical water in addition to the biochemical [8]. Catalytic and semi-hydrogenation, as well as gasification, are used in thermo-chemical biomass reforming to increase the yield of highly liquid and gaseous compounds that can be exploited[9]. Bioethanol, bioethanol-derived vegetable oils, biodiesel, biogas, biosynthetic gas (bio-syngas), biooil, bio-char, Fischer-Tropsch liquids, and biohydrogen are all examples of biofuels. Any fuel that may be burned directly to generate power is referred to as "biofuels." Any chemical molecule in the alcohol family can theoretically be used as a fuel. Methanol $(\mathrm{CH} 3 \mathrm{OH})$, bioethanol $(\mathrm{C} 2 \mathrm{H} 5 \mathrm{OH})$, propanol $(\mathrm{C} 3 \mathrm{H} 7 \mathrm{OH})$, and butanol $(\mathrm{C} 3 \mathrm{H} 8 \mathrm{OH})$ are all alcohols that can be utilized as motor fuels $(\mathrm{C} 4 \mathrm{H} 9 \mathrm{OH})$. The only fuels that can be found in internal combustion engines are methanol and bioethanol (ICEs)[10].

Table 1. Major agricultural crop production in Pakistan[6]

\begin{tabular}{|l|l|l|l|}
\hline Sample & Hemicelluloses & Cellulose & LN \\
\hline Corncob & 32.0 & 52.0 & 15.0 \\
\hline Corn storver & 30.7 & 51.2 & 14.4 \\
\hline Shell of Sunflower & 33.7 & 47.3 & 18.0 \\
\hline Shell of Almond & 28.9 & 50.7 & 20.4 \\
\hline Wheat husk & 37.1 & 29.8 & 17.6 \\
\hline Beech wood form of & 30.8 & 46.8 & 22.9 \\
\hline $\begin{array}{l}\text { Ailanthus } \\
\text { wood }\end{array}$ & 45.7 & 27.2 \\
\hline Spruce wood & 22.6 & 51.8 & 28.5 \\
\hline
\end{tabular}

\section{The current state of energy supply and demand in certain areas}

Pakistan's strategic location, which borders the Arabian Sea, India, China, Iran, and Afghanistan, is expected to act as a regional energy corridor. Pakistan will have to strive for energy self-sufficiency to keep this status. Energy sources are in short supply, and demand cannot be met. Oil, gas, liquefied petroleum gas (LPG), coal, hydroelectricity, nuclear energy, and imported power have all shown increased dependency with yearly average growth rates of 5.6 percent, 3.5 percent, 14.2 percent, 7.5 percent, 0.6 percent, -1.7 percent, and 25.5 percent, respectively [11]. Similar findings were replicated in Pakistan's 2009-2010 economic survey between 2009 and 2010, energy supply fell by -0.64 percent, and energy availability in tonnes of oil equivalent (TOE) fell by -3.09 percent per capita. Pakistan will have to fund 29.06 percent of its energy deficit in 2021-2022, based on existing resources and speed[12], for the following ten years. To meet its goal to create energy from the finest sustainable energy sources, the European Union (EU) has mandated that each member country generate at least 22.1 percent of its electricity from renewable resources. Pakistan would be able to meet its energy needs while maintaining its reputation as an environmentally benign country if it followed the same code of behavior [13]. 


\subsection{Biogas and fertilizer potential}

As an agro-livestock-based economy, Pakistan has substantial biomass resources in the form of crop leftovers, dung and manure, chicken litter, sugarcane bagasse, and wood [14]. Electricity generation from biofuels is one of the most practical solutions; biomass generates roughly 9 Giga Watts of electricity globally. Pakistan is the world's fifth-largest sugarcane grower, producing 50 million tonnes of sugarcane and 10 million tonnes of bagasse each year. According to estimates [15], there are roughly 80 sugar mills with the capacity to create nearly 3000 MW of energy through biogas processing, although they are currently functioning at $700 \mathrm{MW}$. The livestock industry is expanding at a rate of $4 \%$ each year. In rural areas, there are over 159 million animals, and their excrement can be used to make biogas. Animal feces energy production is extremely sustainable because it is economically viable, socially acceptable, and environmentally friendly [16]. Table 3 shows that the United States has around 65.2 million cattle and buffalo. 652 million $\mathrm{kg}$ of dung would be created if an average animal produced $10 \mathrm{~kg}$ of manure per day. The total will be 326 million $\mathrm{kg}$ if $50 \%$ of the treated excrement is collected and used for biogas processing. A $20 \mathrm{~kg}$ wet amount of manure would produce 1 cubic meter $(\mathrm{m} 3)$ of biogas, according to estimates[17]. As a result, around 16.3 million $\mathrm{m} 3$ of biogas is produced each day. Biogas will meet Pakistan's rural population of over 112 million people's cooking and other energy needs. In Pakistan, citrus pulp, paper, abattoir waste, and street garbage all have the potential for biogas production. Poultry waste can be used to create biogas. Rice straw emitted the most methane when compared to other biogas supplies like the cotton gin, but when the cotton gin was mixed with livestock dung and fermented, it produced more gas in a shorter length of time [18]. According to this, rice straw and cotton waste can also be used to generate electricity. Pakistan can produce 21 million tonnes of biofertilizer per year in addition to coal. According to a study, the phosphorus concentration of cow farm manure ranges from 4100 to 18,300 $\mathrm{mg} / \mathrm{kg}$ of dry matter. According to a survey, plants had access to 19 percent fresh manure nitrogen, 37 percent phosphorus, and 29 percent potassium after accounting for all losses, allowing them to compensate for approximately 20 percent nitrogen and 66 percent phosphorus accessible in the fields. Organic manures can help farmers save money on commercial fertilizers by enhancing soil fertility and offering a low-cost energy source[19].

Table 2. Livestock strength in Pakistan[20]

\begin{tabular}{|l|l|}
\hline Buffaloes & 30.4 \\
\hline Camel & 1.2 \\
\hline Sheep & 28.6 \\
\hline Cattle & 34.1 \\
\hline Equines & 5.4 \\
\hline Goats & 57.6 \\
\hline
\end{tabular}

\subsection{Pakistan's biogas historical context and current circumstances}

In China and India, biogas is a growing industry. Up to 2007, China had 6.8 million household digesters and 1000 medium and large-scale digesters in operation, producing 2 million $\mathrm{m} 3$ of gas and accounting for $5 \%$ of the total national gas output. To exploit the potential of cattle waste, Tibet introduced the residential biogas model (RBM), which has had a positive impact on the region's socio-economic conditions. Biogas plants have been attempted in Pakistan, with the first known biogas plant using farmyard manure being constructed in Sindh in 1959 [21]. In 1974, the Pakistani government was first made aware of household biogas plants as a renewable energy source. PCAT (Pakistan Council for Appropriate Technology) used Chinese fixed dome technology to build 21 
biogas plants. These plants were unable to function due to gas leakage from hairline cracks in their construction. Following that, the Indian design was approved, and 10 demonstration units were built in Azad Jammu and Kashmir (AJK). Because of their performance, these units were adopted for mass manufacture [22]. Meanwhile, the Directorate General of New and Renewable Energy Resources (DGNRER) began work on a 4000 biogas plant project in 1986. This three-tiered project includes 100 government-sponsored demonstration units in the first phase, a 50\% subsidy in the second phase, and continued technical help to motivate individuals in the third step [23]. Due to a lack of government support, exorbitant technical expenses, a lack of successful community training, insufficient demonstration, and low motivation, the program failed. With the help of the Pakistani government, the Anaerobic Digestion Support Program (BSP) was launched in 2000 to install 1200 residential biogas units. The program's initial aim of building 10,000 biogas plants in the next five years was met, accounting for $27 \%$ of Pakistan's total biogas capacity. The Pakistan Dairy Production Company (PDDC) is building biogas units as part of its Horizon-3 effort to deliver low-cost alternative renewable energy to rural areas. As of May 13, 2009, over 450 biogas plants have been installed. However, the number of implementations quickly climbed to 556 by July 2009, owing to a significant reaction [24]. with expenses ranging between 35,000 and 40,000 PKR per biogas unit, each of these home units can be powered by the dung of 4-6 buffaloes and/or cows. Farmers who use the PDDC are also eligible for a subsidy of 50 percent. The Rural Support Programs Network (RSPN) began a biogas production program in 2009, with 70 units deployed in the first year. People can select from a range of unit sizes based on their needs and capacities, as well as receive a subsidy of RKR 7500. The Nepalese GGC 2047 fixed dome architecture is used in the Domestic Biogas Program. To market this technology in Pakistan, leaflets, brochures, TV and radio shows, farmer meetings, and manuals have all been employed. The Alternative Energy Production Board is updating policies and actively engaging with all stakeholders to develop renewable energy from biomass [24]. The Pakistan Council for Renewable Energy Technologies (PCRET) has built nearly 1500 household-sized biogas units, three community-sized plants, and one major thermophilic facility, as according to sources, however, these units have been failing for a long time, making large-scale biogas plants relying on Japanese technology pruden[25].

\subsection{Biogas has several advantages over traditional fuels in terms of cost}

Traditional biofuels including LPG, fuelwood, dung cakes, and chemical fertilizer cost around 3550 PKR, while healthcare costs are around 1000 PKR. Each month, 600 PKR of chemical fertilizer will be replaced by bio-slurry [26]. Community organizations in Punjab, on the other hand, said that biogas plants produced enough gas to meet their daily needs and that they were considered superior to traditional biomass energy sources. When all of the above data are summed up, a biogas unit can save up to 5150 PKR every month, proving that biogas systems are economically viable. A methane digester with a $10 \mathrm{~m} 3$ capacity saved 7672 PKR per month and 92,062 PKR per year, according to another source. The overall cost of $5 \mathrm{~m} 3$ is $35,000 \mathrm{PKR}$, resulting in a gas output cost of only 7000 PKR per cubic meter [27]. It is common knowledge that the cost of a biogas plant may be decreased only if the plant and the gas produced are utilized effectively. According to a study titled "Optimal biogas plant size daily biogas consumption pattern \& traditional fuel saving," In Nepal, the entire amount of dung collected from yards is not fed to the biogas digester, with only $4.77 \mathrm{~kg}$ of dung/cubic meter of digester fed in the hills and Terai regions, respectively [28]. Among the indirect benefits, a large reduction in diseases was observed; a study on the subject was undertaken in Nepal, and the results showed a considerable decrease in infirmities and sources of energy, as shown in Figure. 1 [29]. Women's opportunity cost with conventional fuels was 47.09 percent of household income, 
according to a study on household biogas models in Panam, Tibet, and China. Biogas units increased household income and reduced women's potential costs.

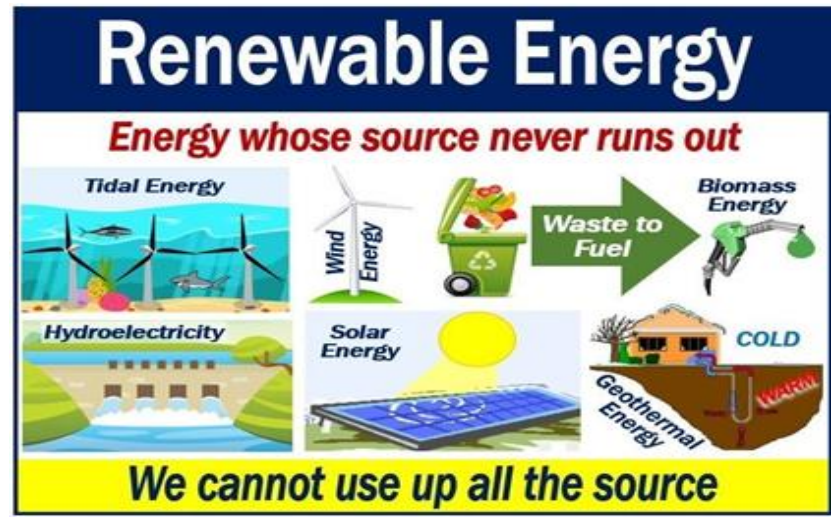

Figure 1. Renewable energy source

\section{Biofuels from lignocellulosic biomass}

\subsection{Biofuels}

Biofuel is the world's most abundant biofuel, and it's being studied as a replacement for gasoline and other transportation fuels. Ethanol is an important precursor as well as an efficient organic solvent for the manufacture of a variety of valuable chemicals and composites[30]. Starch and sugar-derived molecules were used to make commercially manufactured first-generation $(1 \mathrm{G})$ ethanol (sugarcane, corn). The worldwide society was hostile to this technology due to ethical concerns regarding the conflict of food vs. fuel utility and the encroachment of vast farmlands for cultivating food crops as the primary feedstock for fuel generation[31]. The synthesis of biofuel from lignocellulose feedstock is referred to as second-generation $(2 \mathrm{G}$ ) bioethanol because of its clean combustion properties, low carbon output, minimal toxicity, and volatility. The use of $2 \mathrm{G}$ ethanol has the potential to reduce reliance on fossil fuels and greenhouse gas (GHG) emissions while also providing good environmental benefits[32]. Even though $2 \mathrm{G}$ ethanol production is still in its early stages, wellknown businesses including DuPont, GranBio, Poet-DSM, Razen, and Abengoa have invested in commercial units. Bioethanol synthesis can also be done via thermochemical and biological processes. In both procedures, the refractory lignin moiety is reduced to simple fragmented intermediate molecules, which are then converted to ethanol. The Fischer-Tropsch catalytic process is used to produce syngas ( $\mathrm{CO}$ and $\mathrm{H} 2$ ) and convert it to ethanol, hydrocarbon fuels, butanol, and green diesel. Enzymatic hydrolysis (using Clostridium sp.) can also be used to create bioethanol from syngas fermentation[33]. Hydrolysis of lignocellulose components into monosaccharide (sugar) units can be aided by cellulase and hemicellulase enzymes, which can then be fermented using yeast and bacteria to produce ethanol. However, the complexity and high cost of pretreatment technologies, as well as the economic and technological feasibility of the biomass conversion process, are two of the most critical issues in bioethanol production[34].

\subsection{Biochemicals made from lignocellulosic biomass}

Enzymatic or acidic hydrolysis is used to depolymerize the carbohydrates (polysaccharides) found in cellulose and hemicellulose components in lignocellulose into monosaccharide sugar units (such as glucose and fructose) and soluble intermediates in the current scenario[35]. The obtained sugar components are derivatized into a variety of value-added organic chemicals, such as 5- 
hydroxymethylfurfural (HMF), furfural, levulinic acid (LA), and 2,5-furan dicarboxylic acid (FDCA), -valerolactone (GVL), 2,5-dimethylfuran (DMF), diols, ethanol, and liquid alkanes, through selective synthesis processes. This section focused on advanced reaction systems and selective catalytic approaches for the synthesis of value-added compounds like HMF, LA, and FDCA, as well as recent developments and hurdles in converting lignocellulosic biomass into valueadded biochemicals [36].

\section{High-value bioproducts can be made from lignocellulosic materials}

Biofuels and low-molecular organic molecules such as ethanol, methanol, acetic acid, formic acid, 5-hydroxymethyl furfural, and other derivatives are made from the carbohydrate parts of lignocellulose, cellulose, and hemicellulose. The refractory lignin macromolecular component is used to make synthetic aromatic polymers like polyimide, resins, thermoplastics, and composite films. As a result, the cascade utilization of biomass, which involves various pretreatment procedures followed by a separation process of the individual biomass component, is an effective approach for greener technology to systematically produce diverse bioproducts, as opposed to other inefficient thermochemical and biochemical methods[37]. Among the various pretreatment procedures, supercritical fluids (CO2, $\mathrm{H} 2 \mathrm{O}$, and ethanol), ultrasonic irradiation, electromagnetic field perturbation, hydrodynamic cavitation, and ionic liquid (IL) pretreatment protocols have been identified as the most effective for dissolving and hydrolysis of biomass components. Lignocellulosic biomass, such as corn and wheat straw, is used to create high-value bioproducts. Biomaterials made from lignin Vanillin, guaiacol, bioethanol, carbon-based nanomaterials, bioplastics, color dispersants, and aerogels are just a few of the important bioproducts made from lignin. Furthermore, lignin is a viable carbon precursor for manufacturing plentiful carbon due to its low cost, abundance, renewability, and substantial source of high-quality carbon. Aqueous nanomaterials include carbon nanotubes (CNTs), fullerenes, graphene, and graphene quantum dots (GQDs), as well as other carbon-based materials such as porous, hard activated carbon, biochar pellets, and nanocomposites. Carbon compounds are in significant demand in the energy sector, where they are employed in photocatalysts, supercapacitors, and lithium-ion batteries as low-cost energy storage materials [38]. Colors are important coloring reagents that can be found in a wide range of household and commercial items, including paper, plastic, textiles, rubber, and leather. Some of the colors accessible are direct, vat, reactive, dispersion sulfur, acidic, basic, and solvent dyes. Dye dispersants are an important aspect of the dyeing process since these colors are difficult to spread consistently in water without the assistance of dispersing ingredients [39]. Lignin-derived dye dispersants have sparked a lot of attention due to their unique qualities of high adsorption, high dispersive ability, excellent thermal stability, environmental friendliness, and durability. The main sources of these color dispersants are sodium lignosulfonate (NaSL), naphthalene sulfonate formaldehyde (NSFC), hydroxypropyl sulfonated alkaline lignin (HSAL), and alkali lignin. Because of the presence of multiple reactive functional groups such as aliphatic, hydroxyl, carbonyl, carboxyl, and methoxy moieties, as well as feasible glass transition temperatures (Tg; 90-170C) and thermoplastic quality, lignin-derived bioplastics such as use-and-throw carry bags and recyclable plastic items have recently gotten a lot of attention[40].

To avoid the creation of non-biodegradable polymers and environmental contamination, these are seen as a cost-effective and long-lasting alternative to petroleum-based polymer plastics. Aerogels are a form of sophisticated solid-state material with unique physicochemical properties, including as 
open mesoporous framework structures with $99.9 \%$ ultra-porosities, a high surface-volume (internal voids), or mass ratio, massive pore volumes, and extremely low density [41].

\subsection{Lignocellulosic Biomass Composition}

The woody biomass is divided into two categories: hardwood and softwood. Lignin concentration is higher in softwood (26-34 percent) than hardwood (23-30 percent). As a result, the chemical structures differ, with softwood lignin-containing guaiacyl units and hardwood lignin-containing guaiacyl and syringyl units. The content of each component varies with the type of biomass[42]. Typical lignocellulosic biomass comprises roughly 40-50 wt. percent cellulose, 20-40 wt. percent hemicellulose, and 10-40 wt. percent lignin. The percentage contents of the main components of lignocellulosic biomass in softwood and hardwood are shown in the graph.

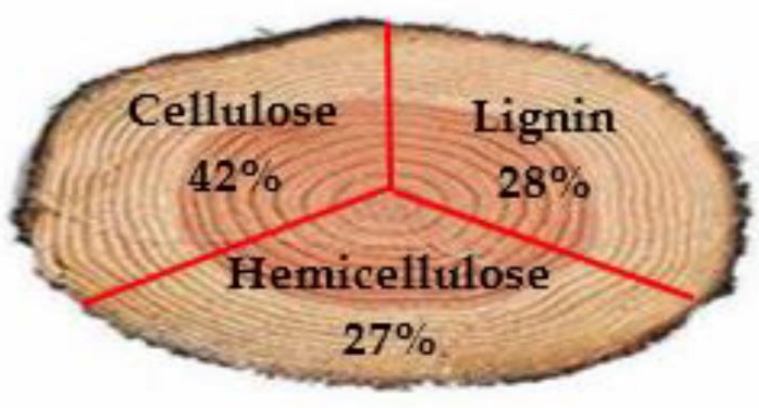

(a)

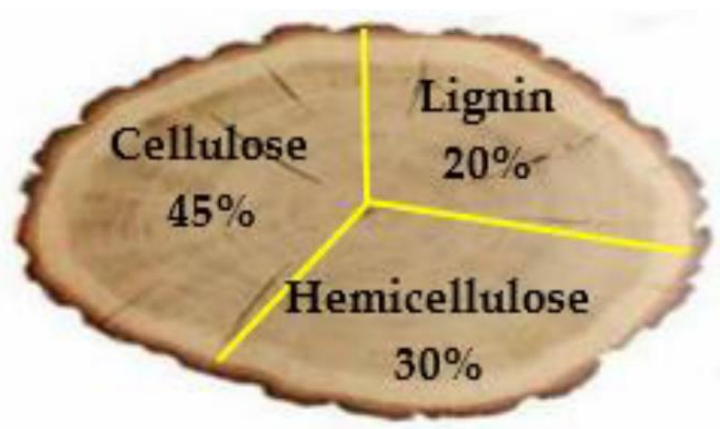

(b)

Figure 2. Percentage contents of key constituents of biomass into a wood cell. (a) Softwood (b) Hardwood [43].

\section{Materials made from lignocellulosic biomass}

\subsection{Lignocellulosic material is readily available}

Raw material prices are also highly volatile, which has a significant impact on bioethanol production costs. Lignocellulosic materials are a low-cost, plentiful feedstock for manufacturing bioethanol from renewable resources. The US Department of Energy invested nearly $\$ 1$ billion in lignocellulosic bioethanol companies in 2007 , to lower the price of the fuel to $\$ 1.33$ per gallon by 2012. Even while the EU makes a smaller contribution, it is still significant [44]. Depending on the type of resource, lignocellulosic materials are referred to as forest residues, urban solid waste, waste paper, and crop leftovers. Several research on the exploitation of rice straw and other lignocellulosic wastes, stover (corn stover) [45], switchgrass, palm bagasse, and other wastes have been accepted for publication in peer-reviewed journals. The annual production of bioethanol from lignocelluloses could reach 442 billion liters. Rice straw has one of the highest levels of lignocellulosic waste on the planet. Africa produces 20.9 million tonnes per year, compared to 667.6 million tonnes in Asia, 3.9 million tonnes in Europe, 37.2 million tonnes in America, and 731 million tonnes in Oceania (1.7 million tons). Rice straw will produce the highest bioethanol of any biomass feedstock, with 205 billion liters produced per year[46]. This method is also known as saccharification. The final product is glucose, a six-carbon sugar. Hemicellulose is a branching polymer composed of sugars with five (pentoses) and six (hexoses) carbon atoms that accounts for 20-40\% of total dry matter in feedstocks. Sugars with five carbons, such as xylose and arabinose, as well as galactose and glucose, and 
mannose, make up hemicellulose (six-carbon sugars). Hemicellulose is easier to hydrolyze than cellulose because of its branching, amorphous shape. The most common sugars in hemicelluloses are mannose in softwoods and xylose in hardwoods and agriculture wastes [47].

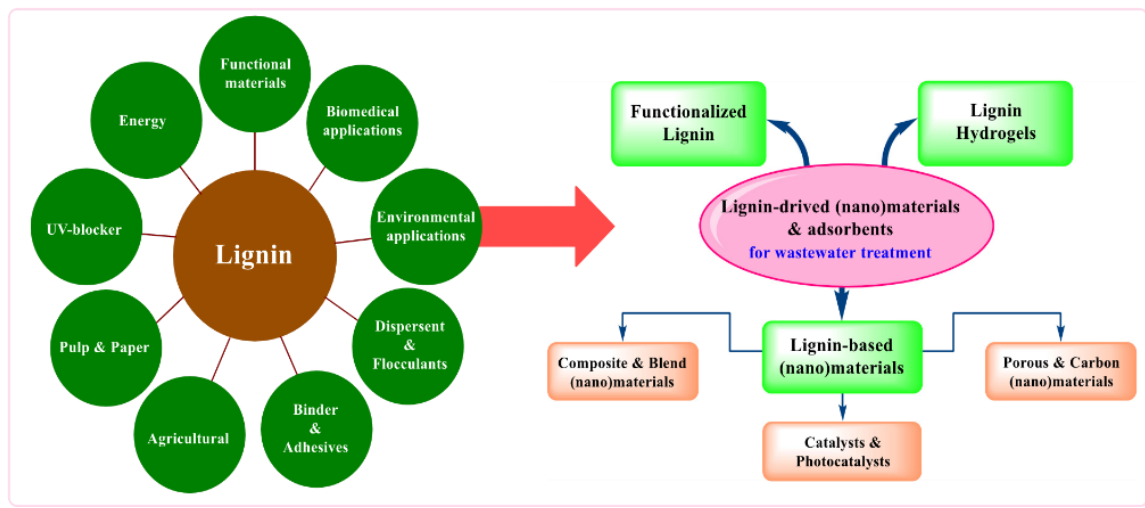

Figure 3. Various applications of extracted lignin and lignin-derived (nano)materials

\subsection{Drivers and significance of biofuels}

Due to the depletion of oil reserves and rising energy consumption, Pakistan is experiencing an energy crisis. As a result, new energy sources are required. Due to some of its unique qualities, bioenergy from biomass has become a reality in many nations throughout the world (Table 4) to meet the increasing demand for energy [48].

- Emissions of greenhouse gases are being reduced

- A freely accessible source that can be used in a variety of ways

- increasing rural economic diversification

- Energy reliability and security

- Reduce the rate at which land erosion occurs.

Table 3. Biomass total supply of primary energy (TPES) in various countries, 2016

\begin{tabular}{|l|l|l|l|l|l|}
\hline Sr.no & Country & $\begin{array}{l}\text { Types of raw } \\
\text { material (EJ) }\end{array}$ & $\begin{array}{l}\text { (TPES per capita) } \\
(\mathbf{G J})\end{array}$ & $\begin{array}{l}\text { (TPES per GDP) } \\
(\mathbf{M J} / \mathbf{s})\end{array}$ & $\begin{array}{l}\text { Like raw biomass } \\
\text { share inPES (\%) }\end{array}$ \\
\hline 1. & Brazil & 4.07 & 16.89 & 2.99 & 28.30 \\
\hline 2. & Indonesia & 2.31 & 8.24 & 6.33 & 24.44 \\
\hline 3. & China & 8.39 & 7.81 & 6.05 & 16.99 \\
\hline 4. & Pakistan & 1.26 & 6.96 & 8.92 & 5.59 \\
\hline 5. & USA & 5.11 & 13.11 & 0.27 & 34.52 \\
\hline 6. & India & 8.41 & 6.72 & 5.78 & 22.46 \\
\hline
\end{tabular}

\subsection{For Pakistan's economy, bioenergy has many advantages over fossil fuels}

Environmental problems have emerged as a result of urbanization and improvements in the manufacturing sector and processes. VOCs cause the release of harmful greenhouse gases (GHGs), causing serious environmental issues. Petroleum products are a significant source of energy and the main mode of transportation in almost every industry [49]. For long-term growth to be feasible, these issues must be addressed on a long-term basis. Renewable energy is proving to be a viable and dependable solution to environmental concerns in this regard. Bioenergy extracted from biomass has gotten a lot of coverage in recent years. Bioenergy has a slew of environmental advantages, as mentioned below[50];

- GHG pollution reduction

- Power that is renewable or biodegradable 
- Providing both economic growth and work prospects

- Cost-effective and widely available

- Reduce the volume of waste in landfills

- Energy efficiency and dependability

- Reduce the use of fossil fuels

- It can be used to make a variety of items (i.e. ethanol)

\subsection{In Pakistan, bioenergy is being exploited}

In the future, biomass would be a major source of renewable energy. Many obstacles must be overcome to achieve long-term bioenergy development[51]. Several aspects of biomass used for bioenergy production need special attention due to its complexities.

\subsection{Biomass \& bioenergy}

Bioenergy is a renewable energy source derived from organic materials (biomass) derived from living or recently living animals (not fossils). The biologically generated material is composed of carbon, oxygen, and hydrogen, as well as chemical energy that may be turned into thermal, mechanical, and electrical energy. As either a result, the term "bioenergy" refers to all forms of energy derived from biomass. Bioenergy fuel can be made from plant materials such as wood, grasslands, crops, grains, fruits, vegetable oils, agricultural waste, forestry residues, and algaederived biomass; animal materials such as animal fats, animal waste, blood, and milk; and human waste such as municipal solid waste, industrial waste, food processing waste, and sewage. The total quantity of carbon in all biomass on the planet is estimated to be around 550 billion tonnes, with terrestrial vegetation outnumbering marine biomass by two orders of magnitude [52].

\subsection{Bioenergy potential of municipal solid waste (MSW) in Pakistan}

Pakistan, being a densely populated country, has huge MSW generating potential, which we calculated for the top ten cities in the country. With a calorific value of $6.89 \mathrm{MJ} / \mathrm{kg}$, MSW is a mixture of organic and inorganic components [53]. In Pakistan, MSW contains a high percentage of organic components (up to 64\%) and produces 97-114 m-3 biogas per tonne of MSW [54]. We used a collection rate of 55\%, a 50\% organic component, and an MSW biogas production rate of 100 m3/tonne. In 10 main cities in Pakistan, we calculated a total quantity of 20,478 tonnes of MSW per day, of which 5631 tonnes per day is the natural component of MSW that can be used for bioenergy generation. This amount of MSW has a 449 MW electricity generating capacity and can provide roughly $11 \mathrm{GWh}$ per day to the grid (4000 GWh yearly). It has a biogas potential of 0.56 million m3/day (205 million m3/year) [57].

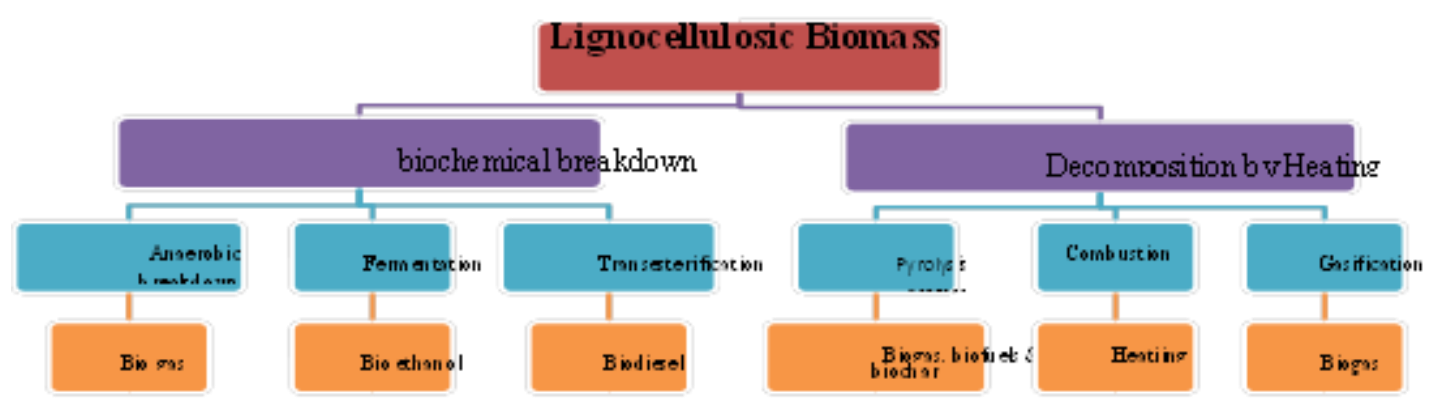


Figure 4. Steps involved in conversion of bioenergy from biomass

\section{Conclusion}

In this paper, The researchers were inspired by the abundance of lignocellulosic trash to employ this low-cost source for biofuels. This is much less expensive to purchase and operate. We researched and extracted lignin from biomass, then used pyrolysis at high temperatures in the absence of oxygen to degrade the lignin substance into biochar. The effects of pyrolysis kinetic parameters, as well as factors affecting pyrolysis parameters like heating rate, temperature, particle size, and moisture content, on the pyrolysis process and product quality, were investigated. Knowledge gaps were also identified, as well as potential future study directions. Till the recent past, energy demand is increasing due to population growth in Pakistan. There are available biofuels energy systems that can be utilized as a feasible resource. As an agricultural-based country, this resource emerges as less expensive due to low running costs. There is an organization that tends to this renewable energy technology and there is exigency of government policy to deploy this potent technology at farmer's doorstep. In this regard, there can also be developed techniques such as hydrolysis, acid treatment to bring high process intensification of lignin-based biomaterial. These methods may generate bioethanol, which is a transportation fuel used primarily as a gasoline additive in tropical latitudes and traded internationally. The present research delineates the paramount strategy to deploy biofuels reactor systems to encounter an energy crisis.

\section{ACKNOWLEDGEMENT}

The authors are grateful to the employees who supported MUET, Department of Chemical Engineering Jamshoro Sindh, Pakistan, for their important guidance and facility providing in the research work.

\section{CONFLICT OF INTEREST}

There is no conflict of interest stated by the authors

\section{References}

[1] Zuberi M. J. S. \& Ali S. F.(2015). Greenhouse effect reduction by recovering energy from waste landfills in Pakistan. Renew. Sustain. Energy Rev, 44, 117-131.

[2] Chaudhry, M. A, Raza R, \& Hayat S. A. (2009). Renewable energy technologies in Pakistan. prospects and challenges. Renew. Sustain Energy Rev. 13, 1657-1662.

[3] Ghaffar, M. A. (1995). The energy supply situation in the rural sector of Pakistan and the potential of renewable energy technologies. Renew. energy. 6 (8), 941-976.

[4] Asif, M. (2009). Sustainable energy options for Pakistan. Renew. Sustain. Energy. 13 (4), 903-909.

[5] Ilyas, S. Z. (2006). A case study to bottle the biogas in cylinders as source of power for rural industries development in Pakistan. World Appl. Sci. J. 1(2), 127-130.

[6] Mirza,U. K., Ahmad,N. \& Majeed,T. (2008). An overview of biomass energy utilization in Pakistan. Renew. Sustain. Energy Rev. 12(7), 1988-1996.

[7] Chen,D. Gao,A. Cen,K. Zhang, J. Cao,X. \& Ma, Z. (2018). Investigation of biomass torrefaction based on three major components: Hemicellulose, cellulose, and lignin. Energy Convers. Manag. 169, 228-237.

[8] Sahir M. H. \& Qureshi, A. H.(2008). Assessment of new and renewable energy resources potential and identification of barriers to their significant utilization in Pakistan.Renew. Sustain. Energy Rev. 12(1), 290298. 
56 Siddique et al.: A comprehensive review of lignocellulosic biomass and potential production of bioenergy as a renewable resource in Pakistan

[9] Book,P. E. Y. (2009).Hydrocarbon Development Institute of Pakistan. Publication and Information Disseminatio.

[10] Coyle Eugene, D. Simmons Richard, A. (2014). Understanding the global energy crisis.USA: Purdue University Press e-books.

[11] Holdren, JP. (1991). Population and the energy problem. Popul Environ: 231-55.

[12] Amin, S. (2013). Solution for energy crisis in Pakistan. Pakistan: IPRI Publications.

[13] Asif, M.(2009). Sustainable energy options for Pakistan. Renew Sustain Energy Rev.13(4), 903-909.

[14] Rao,P. V. S. Baral, S., R. Dey, \& Mutnuri, S. (2010). Biogas generation potential by anaerobic digestion for sustainable energy development in India. Renew. Sustain. energy Rev. 14(7), 2086-2094.

[15] Demirer, G. N. \& Isci, A. (2007). Biogas production potential from cotton wastes.Renew Energy. 32, 750757.

[16] He,Z. T. S. Griffin, \& Honeycutt, C. W. (2004). Phosphorus distribution in dairy manures. J. Environ. Qual.33( 4), 1528-1534.

[17] Amjid,S. S. M. Q. Bilal, Nazir,M. S. \& Hussain, A. (2014). Biogas renewable energy resource for Pakistan. Renew. Sustain. Energy Rev., vol. 15( 6), 2833-2837.

[18] Barker,J. C. J. P. Zublena, M. B. Coelho, \& Kornegay, E. T. (1996). Livestock manure nutrient assessment. Phytase Anim. Nutr. waste Manag. 17-27.

[19] L. Jingjing, Z. Xing, DeLaquil, P. \& Larson, E. D. (2001). Biomass energy in China and its potential. Energy Sustain. Dev. 5(4), 66-80.

[20] Mushtaq, K. A. A. Zaidi, \& Askari, S. J. (2016). Design and performance analysis of floating dome type portable biogas plant for domestic use in Pakistan. Sustain. Energy Technol. Assessments. 14, 21-25.

[21] Ilyas, S. Z. (2006). Biogas support program is a reason for its success in Pakistan. Am. J. Sci. Res. 1(1), 42-45.

[22] Mushtaq, K. Zaidi, A. A. \& Askari S. J. (2016). Sustainable Energy Technologies and Assessments.

[23] Naqvi S. R. et al.(2018).Potential of biomass for bioenergy in Pakistan based on present case and future perspectives. Renew. Sustain. Energy Rev. 81, 1247-1258.

[24] Rahim, A. M. A. Hussain, Rashid, M. Khan S. \& Rahim W. (2020). Role of Biomass in the Mitigation of Energy Crises in Pakistan.

[25] [25] Slade,R. Bauen, A. \& Shah, N.(2009).The greenhouse gas emissions performance of cellulosic ethanol supply chains in Europe. Biotechnol. Biofuels. 2(1), 1-19.

[26] Campbell, J. E. (2010).Integrating the sustainable energy portfolio: a bioenergy perspective. Taylor \& Francis.

[27] CHINNADURAI,K. K. MUTHUKUMARAPPAN, and JULSON, J. L. (2008).Enzymatic Hydrolysis of Corn Stover Pretreated in High Shear Bioreactor.

[28] Taherzadeh,M. J. \& Karimi,K. (2008).Pretreatment of lignocellulosic wastes to improve ethanol and biogas production: a review. Int. J. Mol. Sci. 9(9), 1621-1651.

[29] Demirbas,A. (2007). Products from lignocellulosic materials via degradation processes," Energy Sources, Part A Recover. Util. Environ. Eff. 30(1) 27-37.

[30] Singh,N. Kumar, B. A.\& Rai,S. (2014). Potential production of bioenergy from biomass in an Indian perspective. Renew. Sustain. Energy Rev. 39,65-78.

[31] MOMETE,D. C. (2011). Analysis of sustainable biomass: a three-dimensional approach. energy.1009,

[32] Dincer,I. (2000). Renewable energy and sustainable development: a crucial review. Renew.Sustain. energy Rev. 4( 2), 157-175.

[33] Edenhofer O. et al., (2011). Renewable energy sources and climate change mitigation: Special report of the intergovernmental panel on climate change. Cambridge University Press.

[34] I. A. Mirza \& M. S. Khalil, (2011). Renewable energy in Pakistan: opportunities and challenges. Sci. Vis. $16,13-20$.

[35] Mirza, U. K. Ahmad,N. K. Harijan, \& T. Majeed, (2009). Identifying and addressing barriers to renewable energy development in Pakistan. Renew. Sustain. Energy Rev. 13(4), 927-931.

[36] Shah,A. A. S. Qureshi,M. hutto,A. B \& Shah,A. (2011). Sustainable development through renewable energy - the fundamental policy dilemmas of Pakistan. Renew. Sustain. Energy Rev. 15(1), 861-865.

[37] M. F. Aziz \& Abdulaziz,N. (2010). Prospects and challenges of renewable energy in Pakistan.in IEEE International Energy Conference. 161-165. 
[38] Akhter,F., Soomro, S.A., Jamali, A. R., Chandio, Z. A., Siddique, M., Ahmed, M. (2021).Rice husk Ash as green and sustainable biomass waste for construction and renewable energy applications. a review.

[39] Akhter F. \& Siddique, M. (2021). Plant and Non-plant based Polymeric Coagulants for Wastewater Treatment : Plant and Non-plant based Polymeric Coagulants for Wastewater Treatment : A Review .33(2).

[40] Goyal HB, Seal Diptendu, Saxena RC. (2008). Bio-fuels from thermochemical conversion of renewable resources: a review. Renew Sustain Energy Rev.12, 504-17.

[41] McKendry Peter. V(2002). Energy production from biomass (part 1): overview of biomass. Bioresour Technol. 83, 37-46.

[42] Bar-On, Y.M., Phillips, R., Milo, R., (2018). The biomass distribution on earth. Proc. Natl. Acad. Sci. U. S. A. 115, 6506-6511

[43] Siddique, M. Ahmed, S. Aziz, S. \& Akhter F. (2021). An Overview of Recent Advances and Novel Synthetic Approaches for Lignocellulosic derived Biofuels,” J. Kejuruter.33(2), 165-173.

[44] F. Mushtaq et al., "Fluidized bed heat exchange capacity of Alumina, coal-char and bio-char solids," IOP Conf. Ser. Mater. Sci. Eng., vol. 414, no. 1, 2018, doi: 10.1088/1757-899X/414/1/012003.

[45] Siddique, M. Soomr o, S. A., Aziz, S., Jatoi, A. S., Mengal, A. Mahar, H. (2016). Removal of Turbidty from Turbid Water by Bio-cogulant Prepared from Walnut 6(2), 66-68.

[46] Unar, I. N., S. Soomro, A. \& Aziz. S.( 2010). Effect of Various Additives on the Physical Properties of Polyvinylchloride Resin. J. Anal. Environ. Chem. 11(2), 44-50.

[47] Zahid I.(2016). Municipal Wastewater Treatment Using Rice Husk and Kikar. 56-59.

[48] Menon V., Rao, M. (2012). Trends in bioconversion of lignocellulose: Biofuels, platform chemicals \& biorefinery concept. Prog. Energy Combust. Sci. 38 (4), 522-550.

[49] Ahmad, U. M. et al., (2020). Can lignin be transformed into agrochemicals Recent advances in the agricultural applications of lignin. Ind. Crops Prod. 170.

[50] Mushtaq, F. et al. (2018). Fluidized bed heat exchange capacity of Alumina, coal-char and bio-char solids," IOP Conf. Ser. Mater. Sci. Eng., vol. 414, no. 1, 2018, doi: 10.1088/1757-899X/414/1/012003.

[51] Mushtaq, F., Najam, M., Malghani, K., Nasar, M.S. and Mengal, A.N. (2017). Pyrolysis Heating Performance of Oil Palm Shell Waste Biomass with Carbon Surfces. Journal of Applied and Emerging Sciences. 7(1), 70-75.

[52] Siddique, M., Kakar, E., Soomro, S. A. and Sattar, A. (2014). Particle Size Analysis of Coal and Biomass. Journal of Applied and Emerging Sciences 6(2) 66-68.

[53] Siddique, M. Soomr o, S. A., Aziz, S., Jatoi, A.S., Mengal, A. and Mahar, H. (2016). Removal of Turbidty from Turbid Water by Bio-cogulant Prepared from Walnut. Journal of Applied and Emerging Sciences, 6(2): 66-68.

[54] Wendisch, V.F., Kim, Y. and Lee, J.H. (2018). Chemicals from lignin: Recent depolymerization techniques and upgrading extended pathways. Current Opinion in Green and Sustainable Chemistry 14:33-39.

[55] Zahid, I. et al. (2016): Municipal Wastewater Treatment Using Rice Husk and Kikar. International Research Symposium on Engineering Advancements 2016 (IRSEA SAITM, Malabe, Sri Lanka. 56-59.

[56] Amin, M., Ullah, A., Khan, M. N. and Zeeshan, M. (2016). Effect of Coagulant Extracted From Almond Nutshell (Prunus Amygdalus) on Synthetic Turbid Water. International Research Symposium on Engineering Advancements 2016 (IRSEA 2016) SAITM, Malabe, Sri Lanka: 177-182.

[57] Ayyachamy, M., Cliffe, F.E., Coyne, J.M., Collier, J. and Tuohy, M. G. (2013). Lignin: untapped biopolymers in biomass conversion technologies. Biomass Conversion and Biorefinery. 3(3), 255-269. 